\title{
WHY MUSLIM STUDENTS PLAGIARIZE IN WRITING ENGLISH TEXTS
}

\author{
Wakhid Nashruddin \\ English Department of IAIN Syekh Nurjati Cirebon \\ wahid1n@yahoo.co.id
}

\begin{abstract}
Reasons for copy-pasting someone else's works has attracted attention from many sides that copy-pasting activities, or more popular with term plagiarism, have been considered as a threat for academic life. It also happens at the case of muslim students, in which Islam teaches the students to be honest and not to steal from others. For understanding why it happens, this exploration is conducted. The students of English Department of IAIN Syekh Nurjati Cirebon have to write many of their assignments in English. The result of my observations, the quality of the students' writing is not good enough. One of the cases found is the copy-paste works, or plagiarism. Using interviews instrument, I try to figure out why students of English Department of IAIN Syekh Nurjati Cirebon. There are at least three reasons behind why students act plagiarism; ignorance on the quotation and citation rules, poor writing skills, and the need of instant writing result. This paper tries to explore these reasons.
\end{abstract}

Keywords: Copy-paste, plagiarism, writing in English

Copy-paste activities (referring to act to copy written texts from electronic files, including from files from computers and website, and pasting it into new written texts without using appropriate citation and quotation rules) or plagiarism acts is well known as a very endangering threat for academic lives, which in turn, is an endangering threat to science. With a large amount of plagiarism results, it is very possible that people's mind may not develop as they just "re-upload" other people's mind. It is also very possible, in the case that the show up of such plagiarism products will be only the use of "old" materials.

The case of plagiarism attracted many researchers. In a database on open access journals, data on www.doaj.org, showed 265 writings concerning plagiarism. I believe that in other journals and publications, more people are aware and care with the issue of plagiarism as it has been identified as a threat. It is widely understood that plagiarism is a threat that should be banned.

In Indonesia, in 2012, a case about plagiarism in a highly respectable university in Bandung, Indonesia came up. Three lecturers that want to be promoted as professors identified to do plagiarism. Thing that really made people concern is the fact that they are lecturers; professionals in the area of education. I think, looking at this case, plagiarism can happen anywhere; including the place that many people believe that it is not possible.

Recently, in May 2013, a case of plagiarism also occurred in book writing. This case involves lecturers of another university writing a book. A reader was surprised knowing that about sixty pages of her thesis were quoted without appropriate quotation rules. She sues these lecturers for intellectual property violation.

In Germany, a quite recent case of plagiarism also occurred, involving a minister. His doctoral 
thesis was only a big case that was shown to public. In this developed country, plagiarism is still a problem Some recent cases of plagiarism in Germany affect some politicians to think that numbers of plagiarism still exist and need certain treatment.

The above two examples of plagiarism case in Indonesia and an example of a case from Germany are only a small number out of many unidentified cases. The dangerous of plagiarism is now realized to be harmful to intellectuality of human beings. Knowing this, research in understanding the case of plagiarism has been conducted by many people concern with it.

Some studies about plagiarism, that I am quite familiar with, have been conducted by Cavanillas (2008), Orthaber (2009), Thompson (2009), and Mahmoud (2009). The sources identified as plagiarism mostly are from the internet.

Cavanillas (2008) observed cyberplagiarism in university regulations. This kind of plagiarism grows rapidly as the wide access of internet. He defines "academic cyberplagiarism ... as a form of plagiarism carried out using electronic tools in the university setting." Further, in applying the rules of cyberplagiarism, university needs to prepare two sides; the students and the faculty members, as he put it:

"The success of university regulations on cyberplagiarism require at least two complementary policies: student education, which should include a definition that is sufficiently clear of what cyberplagiarism is and is not; and faculty training, so that they define cyberplagiarism in a uniform way and suitably evaluate the cyberplagiarized tests or exercises."

(Cavanillas, 2008: 11).

So, it is a must that the two sides in the university, which get in touch with cyberplagiarism, understand the dangerous of plagiarism and know how to handle with it.

Further, in the area of Internet-plagiarism, Orthaber (2009) paid attention to identify and avoid plagiarism. She found that some criteria of suspicious works that contain copy-paste contents taken from internet. Her analysis results to suggestions that students who conduct plagiarism should not be punished, but should be motivated for not doing such bad actions (Orthaber, 2009: 24). In addition, it can be suggested that prevention and caution should be done before the students work with their assignments.

Working with academic writing, Thompson (2009) reviewed the issues of plagiarism in university students' academic writing. She studied two cases on the use of "the words and ideas of the authors of their source texts in their research-based assignments" (Thompson, 2009: 1). Her study was to understand the conditions of non-native English writers in writing academic English. In the end, one her analysis is that "these students recognised that the language, ideas and the texts they produced were intricately tied up with accenting and re-accenting the language, ideas and texts of others, or, as Kirsty put it: 'getting your voice in'" (Thompson, 2009: 13-14).

A different way of plagiarism is really demanding for deeper research. Mahmood (2009) discusses a more hazardous act. He explains "what contract cheating is and how it is done." Contract cheating is different from plagiarism that this uses someone else's works and admitted and claimed as one's writing. In his paper, he identifies that:

"Contract Cheating is a new phenomenon, which is becoming an issue of concern at educational institutions in the UK, USA and Western Europe. Contract cheating is a form of academic dishonesty in which a student would pay someone (a contractor) to complete a given piece of coursework and then submit it as his or her own"

(Mahmood, 2009: 1).

As this is more serious than plagiarism, he highlights some the practices of contract cheating, suggestions on spotting it, and recommendations on dealing with it.

Seeing that there are numerous studies relating to plagiarism, I would not highlight 
all studies. The fact that the ideas are related to the concern of plagiarism at university level, I would also continue my own study in university level, too. The current research devotes to understand why, my students as prospective English teachers, practice plagiarism in writing their assignments. This is demanding as they will be models of English users.

Furthermore, another interesting issue is that the students are muslims. In fact, Islam teaches honesty and good values in it. The prophet Muhammad, the perfect example of Muslim, always taught muslims to be honest and to do good things. So, when the students plagiarize, can I say that they break Islamic values? Do they lose their characters as muslims?

Types of Plagiarism

Plagiarism is an act that should be "condemned" that it is a real threat for academicians. By using other people's ideas in writing without giving credits to writers' cited, it is a "crime" in a sense. To make it clear and focus on the discussion, the definition of plagiarism should be noted here. I would like to quote Horrom (2012: viii), referring to JRRD Editorial Policies. He illustrates that:

"plagiarism occurs when authors use material(s) that are not their original work without documentation (accurately citing the source, using quotation marks if necessary, and obtaining appropriate permissions) and extends to text, figures, and other unique materials."

(Horrom, 2012: viii)

This definition identifies that plagiarism is any use of other people's (quoted or cited) words and materials (including pictures, charts, etc.), without precise and traceable reference.

Plagiarism comes in some different format. In general, there are six things that make a writing to be considered contain plagiarism substances. The following are the six things that are regarded plagiarism (Pritee, Grover, \& Malik: 2012):

a. turning in someone else's work as your own b. copying words or ideas from someone else without giving credit

c. failing to put a quotation in quotation marks

d. giving incorrect information about the source of a quotation

e. changing words but copying the sentence structure of a source without giving credit

f. copying so many words or ideas from a source that it makes up the majority of your work, whether you give credit or not.

(Pritee, Grover, \& Malik: 2012)

More specifically, with noting different characteristics of plagiarism, people can be more aware that plagiarism can be in different formats. In grouping different types of plagiarism Pritee, Grover, \& Malik (2012: 71-72) mention five main types of plagiarism, they are plagiarism of ideas, word for word plagiarism, plagiarism of sources, plagiarism of authorship, and miscellaneous plagiarism (slabbing plagiarism, skipping plagiarism, sharing plagiarism, and snipping plagiarism). These different formats of plagiarism can be found in students' works.

\section{Plagiarism of ideas}

Ideas can come to anybody. For this, plagiarism of ideas can be difficult to analyze. However, "claiming credit for someone else's thoughts, ideas or inventions can be called "plagiarism of ideas" (Pritee, Deepak, \& Malik, 2012: 71). This can also happen to area of students working with his/her assignments. An example of it is:

"A student reviewing a book might develop ideas on her own but would be guilty of plagiarism of ideas if she was inspired by a book review (published or unpublished) but didn't mention this review in her own"

(Pritee, Deepak, \& Malik, 2012: 71).

2. Word for word plagiarism

This is the most widely used by students with low level of language skill and limited readings. "Copying the exact expression of someone's writing can be called "word-forword plagiarism"'" (Pritee, Deepak, \& Malik, 2012: 71). To save this condition, Aaron (1993: 
208) suggests the use of quotation mark when writing quoted words and mentioning the reference (e.g. name or internet source).

3. Plagiarism of sources

Plagiarism of sources is another common type of plagiarism. Pritee, Deepak, \& Malik (2012: 71) illustrate that "if writer R uses writer S's citations, without acknowledging that the citations came from $S$, this can be called "plagiarism of sources." Such kind of plagiarism is another popular type of plagiarism. Usually, students, with low academic skill and are rather lazy, do this as it is quick and take less time than reading many references and find what they need. In addition, Pritee, Deepak, \& Malik (2012: 71) remind that "the more serious plagiarism is when the sources are not read by R: the references are simply taken from S's bibliography."

4. Plagiarism of authorship

Another type of plagiarism that exists is plagiarism of authorship, or what Mahmood (2009) calls "contract cheating." This is more dangerous as this is someone else's work that is completely admitted as one's work. Inside the text, it is possible that the features of plagiarism do not exist, but the fact is that the author does not write the text. It can happen everywhere. Pritee, Deepak, \& Malik (2012: 72) illustrate this type of plagiarism by explaining:

"This occurs when a scientist submits a paper that has already been published by someone else, when a student submits an essay written by someone else (such as a friend or someone who has been paid to write it), when an academic is listed as author of work largely produced by a spouse, research assistant or student, or when a subordinate, speechwriter or ghost writer does the bulk of intellectual work for a work produced under the name of a celebrity, politician, corporate executive or someone else with money, position or status. ... Translating an article from another language and publishing it under one's name, as if one had written it, is plagiarism of authorship but not word-for-word plagiarism."
(Pritee, Deepak, \& Malik, 2012: 72)

This is another common type of plagiarism. It can be everywhere around us, not only in the area of education.

5. Miscellaneous Plagiarism:

a. Slabbing plagiarism

Here is another type of plagiarism. A plagiarist can just take from a writing of not his or her own, and use it without giving credits to the author of the text plagiarized. Pritee, Deepak, \& Malik (2012: 72) define that:

"Slabbing plagiarism is the cutting and pasting of entire paragraphs and even whole sections (e.g. an introduction to a published research paper) of material written by another person into a piece of work without acknowledgement, and with little or no change."

(Pritee, Deepak, \& Malik, 2012: 72)

b. Skipping plagiarism

This type of plagiarism is very tricky. Using other's work, a plagiarist try to reconstruct deconstructed texts into a complete work. Pritee, Deepak, \& Malik (2012: 72) identify that:

"Skipping plagiarism is taking every second or third sentence from one or more textual sources and assembling the sentences in order, thereby constructing what may superficially appear to be a coherent document."

(Pritee, Deepak, \& Malik, 2012: 72)

c. Sharing plagiarism

In working their assignments, it is potential that students do this kind of plagiarism. For some reasons, students cannot do their works by themselves and this potentially leads to sharing plagiarism. Pritee, Deepak, \& Malik (2012: 72) characterize that "sharing plagiarism is when two or more students submit the same or very similar material, which may be their original work."

d. Snipping plagiarism

Working with making up one idea and write it is not an easy task. For this, many students are not strong enough and they let it to go to use from some or many resources and use them in one idea. Pritee, Deepak, \& Malik (2012: 72) describe that "snipping plagiarism is 
taking a sentence here and there from one or more sources and incorporating these into a piece of work."

Knowing different types of plagiarism can guide people to understand how plagiarism can occur. Knowing different types of plagiarism can also help people to identify and then reject plagiarism works. This may lead to the more understanding that plagiarism is unacceptable.

\section{Detecting Plagiarism Works}

Detecting plagiarism works is not easy for some cases. However, for high school and undergraduate students, it can be quite easy for the teachers. Teachers know best her or his students' skill and can find it easier when reading the students' works. To some extent, the teachers can read and say that the works submitted are not their students' that it is impossible that the students can write using highly standardized (English) writing.

In identifying works containing plagiarism, it should base the analysis on some types of feature of assumed plagiarism works. Orthaber (2009) identified some "suspicious" plagiarism works. She found that the identification of plagiarism works can be from the following:

- Language, writing style, vocabulary, tone, and grammar were above the students' actual level;

- Pronouns did not correspond to the gender of the text producer;

- Web sites listed in citations were inactive;

- Look of grey letters in the text;

- Strange and poor layout such as more than one font type in a single text, references to hyperlinks, paragraphs with background color, strange texts or lines at the top or bottom of the page were indications that the text was downloaded or copy pasted from the web;

- References to accompanying material that was not included in the text;

- Quotes in the paper did not have citations;

- The length of the paper was considerably longer than instructed;

- Certain information in the copy-pasted text was changed to the extent that the text did not make sense anymore.

(Orthaber, 2009: 21)

Knowing these features can lead people to be able to spot plagiarism works. People should be more aware of this.

In addition, there are more ways to check plagiarism. Instead of features of plagiarism works from Orthaber (2009: 21), Vinod, et.al. (2011: 3), for example, propose five ways in detecting plagiarism. The five ways are:

a. Search engine of internet: easy method, not a full proof method. e.g. Google search

b. Sudden change in grammar/language/ British-American English/ especially when the differences take place in paragraph to paragraph.

c. Change in font style/ font size etc. may have a 'gost writer' background.

d. Search at least on a random basis about the paragraph reference mentioned by the authors.

e. Electronic detection tools which even gives the $\%$ of plagiarism. e.g. Tumitin UK, iThenticate, The Glate Plagiarism screening program, Wcopyfind, EdiTie.com etc.

Vinod, et.al. (2011: 3)

Detecting plagiarism elements can be proof that the suspected plagiarism works are truly plagiarism results. These ways should also be understood so people can detect plagiarism.

Reasons on Why People Plagiarize

To make it clear why people do plagiarism acts, I would like to see Orthaber's study. In her study, Orthaber (2009: 22), she found out that the students do plagiarism for some reasons. The reasons range from the degree of a subject to students inability to manage their time. The reasons are:

- ... The majority of students may believe the course, its assignments and thus the consequences of cheating to be less important or unimportant.

- With many course assignments being of 
extremely generic nature, students may think that it is their right to copy them off the internet.

- One of the main reasons is also believed to be the fear of holding presentations in a foreign language, which for some students, whose command of the English language was not fluent, was face threatening and stressful. For this reason students were not willing to paraphrase or rewrite texts written by experts or native speakers.

- Until this date no formal action has been taken for plagiarizing assignments and no penalties have been enforced, which also drastically increases students' opportunities for trying.

- The fact that in the middle of the academic year modules have been consolidated from 15 to 8-week intense courses might have affected students' poor time management skills.

Orthaber (2009: 22)

These reasons come up when the students have to do with assignments. They rely on other works to complete their assignments for those reasons. In other words, for other contexts, these reasons may not be usable.

\section{Stopping Plagiarism}

As plagiarism is a very harmful and has been agreed to be destructive, actions have been conducted and will be kept continued. Three sides are interconnected; they are university, lecturers, and students. Without the cooperative working of all these sides, the stop of plagiarism is almost impossible.

A comprehensive action to stop plagiarism has been proposed by Pritee, Deepak, \& Malik (2012: 74). They suggest 18 rules to decrease plagiarism. The 18 rules should be incorporated in the whole process of educating students. Also, it is very important to notice that faculty member of universities know and support these rules. The rules are:

i. Academics should set a good example by giving appropriate credit for sources used in preparing their lectures and notes.

ii. Academics should stop claiming credit for the work of others.

iii. Accentuate the positive and show students how proper citation strengthens their writing and shows they have researched the topic.

iv. Make it clear to students that simply downloading a paper will not help them to develop their ability to analyze or synthesize information, to judge the credibility of sources, or to express them clearly and convincingly.

v. Timetable compulsory sessions on academic writing and citation skills, including the correct citation of electronic sources and teach, by means of discussion and practice, and suggest ways to avoid plagiarism.

vi. Teach students how to recognize acceptable and unacceptable paraphrases.

vii. Include specific instructions regarding correct intext and end-of-text referencing and bibliographies. Ensure teaching staff give consistent guidance. To put it simply, references should be correct, complete, consistent and convincing.

viii. When assessing student work, lecturers should give students feedback on any errors in referencing technique

ix. Explain what should be avoided and what is encouraged in terms of collusion and collaboration.

$x$. Ensure that students know you are aware of essay banks and cheat sites and that you monitor them.

xi. Policies should be written clearly and include illustrations and examples.

xii. Treat all plagiarism as unacceptable, even if it is claimed that it was unintended, and deal with it formally with penalties to fit the circumstances.

xiii. Rewrite or modify the assignment each time the module is taught.

xiv. Decrease the learning outcomes that ask for knowledge and understanding, substituting instead those that require analysis, evaluation and synthesis; consider adding information 
gathering to learning outcomes.

(Pritee, Deepak, \& Malik, 2012: 74)

Furthermore, at the case of university level, all people working with students (when the focus is students' plagiarism) should know, understand, and do action to stop plagiarism. Forums to discuss plagiarism are very important as has been suggested by Neville (2012: 7). He asserts that:

"Providing opportunities for teaching staff and administrators to discuss referencing practice and principles could prove to be useful to staff and students alike. Discussion, leading to the formulation of institutional policies and guidelines, could include key but neglected issues relating to the principles underpinning referencing, including: 'why' and 'when' to reference; what constitutes common knowledge in any discipline; how will referencing be presented to students, including when should this happen, and who will be involved; what advice is offered to students on the selection of sources, particularly those from the Internet; and, importantly, the rationale for the adoption of a particular referencing style or styles within a faculty or institution."

(Neville, 2012: 7)

If this action is done at university, it is believed that plagiarism can be avoided as much as possible. By knowing everything about plagiarism, students should be able to keep away from plagiarism. Plagiarism can be stopped from the work of all elements in university.

\section{METHOD}

This study is qualitative in nature, reflecting on my experiences talking to students of English Department of IAIN Syekh Nurjati Cirebon. The students are prepared to be prospective English teachers. They were assigned to write their assignments in English.

The students are muslims and have received courses about Islam. In my opinion, they are representative of muslim students by label, for they are muslim (they say "syahadah", do shalat, pay zakat, and fast (with do not take into account the fifth pillar of Islam), study at Islamic institute, and learn much about Islamic teachings. In this study, these simple criteria are used.

The participants of this study were about 150 students. However, for practical reasons, I only show the result of my interview with two students; student \#1 is a male and student \#2 is a female. They were considered to represent students caught doing plagiarism and their answers also represents other students' answers.

For this paper, the data was taken from informal interview with students when they submit their works. They were assigned to write research proposals as a completion of Research Methods in ELT course. They submitted the proposals twice, in form of two parts of proposals; the first is the background of the study (submitted as the mid-semester examination), and the second is the method of the research (submitted as the final semester examination).

When they submitted their assignments, they were directly interviewed. The questions were unstructured with some points to explore. The source tracing, the writing format, the citation and quotation ways, and reasons behind why they use certain references were the key points in the interview. Other questions came up also still related to the proposals. One main question asked was about why they conduct plagiarism. This question was directed to students who were caught to do plagiarism in their proposal writings.

\section{FINDINGS}

Reason No.1 Ignorance on the Quotation and Citation Rules

Rules of quotation and citation is an important skill for people working in academic setting, mainly in the education field. By knowing the rules, people can avoid action of plagiarism. This skill should be taught for students.

In my case, in an interview about their submitted assignment, many of their works 
contain plagiarism. When the students were asked about why they do plagiarism, their main answer shows that they do not know how to quote and cite others' works. An answer from students \#1 reflects on this.

"Memang ngga boleh Pak kalau mengambil dari tulisan orang lain?"

(So we cannot use someone else's words?)

(student \#1)

This is a really difficult situation in which the student was not aware that plagiarism is not allowed. This student just thinks that he can just use any people's words in her writing. He looked to be confused when I told her that plagiarism in form of copy-pasting people's woks is not allowed.

When I told her that the source should be mentioned, student \#1 questioned that.

"Oh, sumbernya harus di tulis Pak?"

(Should I mention the source, sir?)

(student \#1)

Knowing this comment from the student, I was a little bit shocked that students do not know that in quoting or using other people's words, they have to mention the author's name.

Student \#2 knows a little about quoting that she should write the reference. However, the way she wrote the reference was not true. She put the writer's name not in the text, in which can lead to the confusion on which parts are her writing and which parts are other people's writing. Asking further question to her, why she did not write the source of the text she quoted, she answered:

"Kan sumbernya di tulis di belakang?"

(I wrote the source at the reference list.)

(student \#2)

Students \#2 did not know how to quote properly. This is also a common problem for students as they do not know how to quote words of others'. Without knowing this, students will keep doing plagiarism.

Feeling desperate for not knowing what and how to quote, student \#2 said:

"Jadi harusnya gimana Pak cara mengutipnya?"
(So how to quote, sir?)

(Student \#2)

Here, she realized that she was wrong and want to learn how to quote and to cite from different readings. The real problem is, they are ignorance on the quotation and citation rules. Students did not learn this skill.

Reason No. 2 Poor Writing Skills

Writing is not a simple skill in learning a language. In fact, it is considered as "the most complex one compared to the three other skills ..." (Cahyono \& Widiyati, 2011: 69). The complexity becomes more complex when the language system is new, for example in writing in a second or foreign language. Furthermore when the language systems, to some extent, of the native language are different with the second and/or foreign language, the complication becomes bigger.

Reading students assignments, I notice that many students plagiarize because they have low skill in writing, in my case, it is writing English. When I compared their own writing with "copypasted" writings, the two were really different. The students writing had many grammatical and spelling errors while the "copy-pasted" writings were perfect. Students' low writing skill promotes plagiarism.

When the questions on why he did plagiarism, student \#1 answered:

"Saya ngga tahu cara nulisnya Pak."

(I don't know how write it)

(student \#1)

Feeling curious with his answer, student \#1 was asked about whether or not he learned how to write properly for quoting, such as paraphrasing, summarizing, and direct quoting. Aaron (1993: 204-205) suggests those three writing skills to avoid plagiarism. Surprisingly, the student \#1's answer was:

"Belum pernah diajarin Pak."

(Never been taught about it, sir.)

(student \#1)

I could not believe this so I asked student \#2 and her answer was:

"Pernah sih..tapi masih bingung." 
(I was taught about this...but I'm still confused with it)

\section{(student \#2)}

Students writing skill was poor. This reminds me to what Cahyono (2012: 2-3) asserts, that the low mastery of second and/or foreign language is a problem and a cause of plagiarism. Before their English writing skill reach certain level of good command of English, plagiarism will remain a threat.

When the students were caught submitting works with plagiarism inside, they were a little bit wondered, why I could know. Then when I told them that their grammar was not good, they just smiled. It means that they admitted that their writing skills were poor.

\section{Reason No.3 The Need of Instant Writing Result}

Students' main job is learning. This is true as in campus, lecturers give many assignments. If students cannot arrange their time, it would be hard to complete all assignments which they have to work on. Time management is a key to successful study.

When the students were asked about when they did the assignment, they answered range between one week to two days. This is not good as they actually had about seven weeks to complete the assignment. For me, the students were possibly too lazy that they did the assignment in the last minute.

Student \#2 admits that she did the assignment in one week, as she said:

"Udah seminggu ini."

(It's been a week)

(student \#2)

Student \#1 even did it in four days, as he said: Pak."

"Empat hari empat malam begadang

(Four days and nights, sleep late, sir.)

(student \#1)

Knowing these facts, I think that students need more discipline their lives. They have to control all their activities. If they kept ignoring the assignments, it can be fatal in the end; their works fulfilled with plagiarism features and they cannot pass the course.

\section{DISCUSSION}

Islam as a religion teaches its people to be honest and do good things. For this, education should also directed to good values of Islamic teaching. This can be done by the support of knowledge and examples of how to be honest and do good things. In the case of plagiarism, the reasons behind why muslim students plagiarize are really important to be taken into account.

There are three reasons about why muslim students plagiarize. The first is ignorance on the quotation and citation rules. This can come from both lecturers who did not teach how to quote and cite properly, and students who did not pay attention to materials in writing course. The second is students' poor writing skills. This also can come from two sides; they are lecturers of writing courses and the "lazy" students who did not study well. Finally, the third reason is the need of instant writing result. This is because students cannot manage their time and to slow in working the assignments.

All lecturers should teach their students to be aware with plagiarism issue and teach the students how to avoid that. Introducing types of plagiarism, reasons on why people plagiarize, and consequences of doing plagiarism are important points to be told to the students. In the case of my students, it seems to me that not many lecturers warn about the danger of plagiarism. I once noticed, in my experience related to Research Method in ELT course, a lecturer did not check the students' works comprehensively. In that way, the lecturer has lost his chance to warn students about plagiarism.

Lecturers of writing courses have many "home works" as they have to explain and provide examples more on how to write properly, including, the most important is how to avoid plagiarism while writing. As I quoted earlier 
from Aaron (1993: 208) that direct quoting, paraphrasing, and summarizing can be used to help writers avoid plagiarism, lecturers of writing course should teach these skills to the students. More practice on working with these skills is a need to improve students writing skill, mainly in the area of quoting and citing references.

Students, as in my case is the most important side to consider, should also be more "diligent" in many ways. Students should be able to control and manage their activities. Also, they need to reduce wasting time for nothing, such as hang out with their friends in café for nothing. It is necessary, I think, that students write their schedule, mainly the due time or deadline of their assignments. Relying on the schedule, students should be able to put priority on which assignments to complete earlier or later. They should know the progress of each assignment so they can reach their goal, submitting assignments on time with maximum efforts.

\section{CONCLUSION AND SUGGESTIONS}

To sum up, I think it is important to note in the beginning of this section that when muslim students do plagiarism, in my research

\section{REFERENCES}

Aaron, Jane E. (1993). The Little, Brown Compact Handbook. New York: HarperCollins College Publishers.

Cahyono, Bambang Yudi \& Widiati, Utami. (2011). The Teaching of English as A Foreign Language in Indonesia. Malang: State University of Malang Press.

Cahyono, Bambang Yudi. (2012). Plagiarism across Cultures. Malang: Pustaka Kaiswaran.

Cavanillas, Santiago. (2008). Cyberplagiarism in University Regulations. In: R. Comas, J. Sureda (coords.). "Academic Cyberplagiarism" [online dossier]. Digithum. Iss. 10. UOC. [Accessed: 16 September 2013]. (pp. 7-11) http:// context, they did not do it intentionally. Also, it is important to note, again in my research context, the students did not break Islamic values of honesty. The reason why they plagiarized was because they did not understand what plagiarism is.

Ignorance on the quotation and citation rules, poor writing skills, and the need of instant writing result are the reasons behind why they plagiarize. These three reasons do not directly touch areas of doing plagiarism on purpose. It is just a matter of not knowing.

Many students are not aware of the danger of plagiarism. This is mainly because they do not get sufficient information regarding plagiarism. Plagiarism is something new for them, not by the term, but by the real it is. As a result, students committed to plagiarism are many.

To end this paper, I would like to highlight one important thing to do to stop plagiarism. It is a must that all people in university; lecturers, academic staffs, and students to work together to inform the danger of plagiarism, and how to avoid them. The information about this should be sounded from time to time so that the information will also pass from generation to generation.

www.uoc.edu/digithum/10/dt/eng/ cavanillas.pdf

Horrom, Tristan A. (2012). From the Editor's Desk: The Perils of Copy and Paste: Plagiarism in Scientific Publishing. JRRD, Vol. 49, No. 8, pp. vii-xii.

Mahmood, Zaigham.(2009). Contract Cheating: A New Phenomenon in Cyber-Plagiarism. IBIMA Vol. 10, 2009, pp. 93-97.

Neville, Colin. (2012). Referencing: Principles, Practice and Problems. RGUHS J Pharm Sci Vol. 2 Issue 2, Apr-Jun, 2012, pp. 1-8.

Orthaber, S. (2009). Detecting and Preventing Internet-Plagiarism in a Foreign Language E-learning Course. iJAC-Volume2, Issue 2, May 2009 (pp. 20-28) doi:10.3991/ 
ijac.v2i2.619

Pritee; Grover, Deepak; \& Malik, Kiran. (2012). Plagiarism: Problem, Behaviour, and Reduction. IJCSMS International Journal of Computer Science \& Management Studies, Vol. 12, Issue 02, April 2012. pp.70-75.

Schuetze, Christopher F. (2013). New Plagiarism Cases Cause Second Thoughts in Germany. http://www.nytimes.com/2013/03/11/ world/europe/11ihteducside11. $\mathrm{html}$ ?pagewanted=all\&_r=0, retrieved 16 September 2013.

Siswadi, Anwar. (2012). Tiga Calon Guru Besar UPI Ketahuan Menyontek. http:/ /www.tempo. co/read/news/2012/03/02/079387670/ Tiga-Calon-Guru-Besar-UPI-KetahuanMenyontek, retrieved 16 September 2013.

Siswadi, Anwar. (2013). Pengusutan Kasus Plagiat di Unpad Segera Selesai. http://id.berita. yahoo.com/pengusutan-kasus-plagiatdi-unpad-segera-selesai-233429105. html, retrieved 16 September 2013.

Thompson, Celia Helen. (2009). Plagiarism, Intertextuality and Emergent Authorship in University Students' Academic Writing. PORTAL, Vol. 6, No. 1, January 2009, pp. 1-16.

Vinod K.R.; Sandhya.S; Sathish Kumar D; Harani A; David Banji; and Otilia JF Banji. (2011). Plagiarism - History, Detection and Prevention. Hygeia.J.D.Med Vol.3, Issue 1, pp. 1-4.

http://www.doaj.org/doaj?func=search\&temp late $=\& u i L a n g u a g e=e n \& q u e r y=$ plagiari sm, retrieved 16 September 2013.

http://www.nytimes.com/2013/03/11/ world/europe/11iht-educside11. $\mathrm{html}$ ?pagewanted=all\&_r=0, retrieved 16 September 2013. 